This item was submitted to Loughborough's Research Repository by the author.

Items in Figshare are protected by copyright, with all rights reserved, unless otherwise indicated.

\title{
Thrown around with abandon? Popular understandings of populism as conveyed by the print media: a UK case study
}

PLEASE CITE THE PUBLISHED VERSION

http://dx.doi.org/10.1057/ap.2011.3

\section{PUBLISHER}

(C) Macmillan Publishers Ltd.

\section{VERSION}

AM (Accepted Manuscript)

\section{PUBLISHER STATEMENT}

This work is made available according to the conditions of the Creative Commons Attribution-NonCommercialNoDerivatives 4.0 International (CC BY-NC-ND 4.0) licence. Full details of this licence are available at: https://creativecommons.org/licenses/by-nc-nd/4.0/

\section{LICENCE}

CC BY-NC-ND 4.0

\section{REPOSITORY RECORD}

Bale, Tim, Stijn Van Kessel, and Paul Taggart. 2019. "Thrown Around with Abandon? Popular Understandings of Populism as Conveyed by the Print Media: A UK Case Study”. figshare. https://hdl.handle.net/2134/16896. 


\title{
Thrown around with abandon? Popular understandings of populism as conveyed by the print media: a UK case study
}

Tim Bale, Stijn van Kessel and Paul Taggart

Final Version in: Acta Politica, 46 (2), 2011, pp. 111-131.

\begin{abstract}
This article examines the use of the term 'populism' in the UK print media, assessing whether the there is truth in the claim that the media throws the term around with abandon. Our findings indeed indicate that populism is used for a wide range of seemingly unrelated actors across the world, that it is hard to find any logic in the set of policies that are associated with the term, and that populism is, more or less explicitly, regularly used in a pejorative way. Despite these findings we refrain from casting populism as a useless term. We will, however, indicate that the inconsistent vernacular use of the term also hampers a meaningful academic debate about the concept.
\end{abstract}

Keywords: Populism, Media, United Kingdom 


\section{Introduction}

Early in 2008, an article on the US presidential race which appeared in The Economist (see 'The people versus the powerful', 7 February), so enraged one of the readers of that venerable publication that he sent the following letter (published 21 February 2008) to the editor:

SIR - Exactly when did "populist" enter your style guide as the preferred all-purpose pejorative? Given that neither John Edwards nor Mike Huckabee have come anywhere near winning their parties' nomination, it is far from clear that they are even "popular", let alone "populist".

Even assuming that they are popular, what is the objective characteristic (with the emphasis on objective) that would transmute them from being good, wholesome popular candidates into nasty, wicked populist ones? In the absence of an objective definition, "populist" seems to be nothing more than a hollow term of abuse that The Economist hurls at anyone whose opinions are at odds with its own. May I suggest that in future you simply describe such people as "evil". It is easier to pronounce than populist and uses less ink.

Stephen Morris

Coorparoo, Australia

Although the letter was pointed enough to earn publication, anyone who followed The Economist's US coverage after it appeared will know that it had little or no effect - as the outraged Mr Morris pointed out in a second, even more miffed, missive published a few weeks later, its staff continued to 'throw the term "populist" around with abandon'.

All of which raises for us the question of how a crucial part of civil society and the public sphere, the media, uses and abuses a term, and defines a phenomenon, that in recent years has provoked so much scholarly debate. This article examines how the terms populism and populist are employed in the British national 'broadsheet' newspapers. It notes which individuals or political parties the term is applied to and 
where they come from. It examines what appears to constitute populism. And it looks at what qualifies an entity or an individual as a populist. Does populism turn out to be a 'hollow term of abuse', or is it applied more objectively to denote particular policies or a certain personal style? Further, is there an obvious difference between the way right-wing and left-wing outlets use the term?

Finally, and perhaps most interestingly, do the vernacular and the academic usages of the terms populism and populist have much in common, other than a tendency on occasion to create more heat than light? Is there anything that one sphere could or should learn from the other concerning how and when the concepts are best employed, presuming there is value in employing them at all? Or do we find instead that the use of the terms is so loose, so chameleonic, and so promiscuous, that they have become denuded of any real meaning and therefore descriptively - and perhaps politically useless?

We begin by discussing the academic use of the term in some depth. Then follows a section outlining our methodology. The subsequent sections move on to our actual analysis of the articles in the selected newspapers, starting with some general observations and then focussing on the alleged populist actors, the populist issues, the pejorative use of populism and the employment of 'populism' in the different newspapers. The final section concludes and discusses the implications for academics of the way 'populism' is used in the vernacular sense.

\section{The academic use of populism}

Most academic contributions that focus on the concept of populism commence by emphasising the problematic and ambiguous nature of the term. Indeed, there are several fundamental problems hampering a fruitful concept-building process, or even a meaningful debate about this (Taggart and Van Kessel 2009). Scholars have questioned whether the alleged populist movements and parties throughout time and across the world really do have much in common (Ionescu and Gellner 1969, Canovan 1981). Even in their groundbreaking volume on populism, editors Ghiţa Ionescu and Ernest Gellner 
observe that populism is used for and by people from a wide ranging set of political backgrounds, such as socialists as well as liberals, while "some political scientists think that Maoism is a form of populism and Nazism another form" (Ionescu and Gellner 1969: 3).

Although descriptions of populism often involve something like an appeal to the 'common people' and an anti-elitist critique, they are often too imprecise to help us properly pin down which actors are populist or which parties can be classified as populist parties. Indeed, efforts to do so have only been further hampered by numerous scholars who use the term for a broad range of political actors without a clear or explicit definition of the concept. Moreover, as Peter Worsley (1969: 218) observed over forty years ago, it makes it even more difficult that movements being labelled 'populist' rarely identify themselves as such; "typically, there has never been a Populist International, and many movements which others have labelled 'populist' have never themselves used any such label to describe themselves".

Even if scholars could agree on the core characteristics of populism, it is still unclear in what form this populism is expressed. While some scholars use populism to denote a certain personal style or an opportunistic strategy to boost electoral appeal (e.g. Betz 1994), others argue that populism should be treated as a more fully-fledged (thin-centred) ideology (Mudde 2004) ${ }^{1}$. This also has consequences for the classification of populist actors; while in the first approach populism can be treated as a tool that can be employed by any political party, the second approach is likely to lead to a more narrow set of populist cases.

Finally, populism is often used in a pejorative way, or associated with xenophobic political actors. Hans-Georg Betz for instance describes populism as a political strategy; a rhetoric "designed to tap feelings of ressentiment and exploit them politically" (Betz 2002: 198, italics in original). On the other hand, others, while not denying the risks of populist politics, stress that populism emerges when the political elite loses track of the popular will, or when the 'constitutional' as opposed to the 'democratic' pillar of democracy becomes too dominant (Canovan 1999; Mény and Surel 2002; Taggart 2002; 
Abts and Rummens 2007).

All in all, this necessarily brief examination of the academic literature on populism shows that the concept is used in an inconsistent manner. Populism has been defined in different ways, there is no consensus on who can be labelled 'populist', and authors disagree on its normative implications. This paper will now turn to the use of populism in the British print media in order to assess whether the same problems occur in the more vernacular use of the term.

\section{Methodology}

While we touch on the use of the terms in the so-called 'red tops' or 'tabloid' newspapers, we focus our research on what we might term the 'highbrow' end of the UK print media the national 'broadsheet' newspapers. These are the Telegraph, Times, Guardian, Independent, and their affiliated Sunday papers. Using the Lexis Nexis database we selected all the articles containing the words 'populism' or 'populist' in six months, covering two different time periods: October until December 2007, and July until September 2008. The main reason for studying two non-consecutive periods is to make sure the results are not biased due to a particular event attracting a disproportionate amount of media attention in a given period of time. Also, by selecting two different time periods, the results from both points in time can be compared. For instance, as the results will show, the word populism often appears when an election campaign takes place. Comparing the two different time periods can show us whether the actors associated with populism during the election campaign are still associated with the term after (or before) this high profile event.

With regard to the coding of the articles we took into account in which newspaper the article appeared, in which section of the newspaper the article was located, and with which category, or genre, the article could be associated (politics, sports, art, media, other). When it came to all the political articles we assessed, we also looked at whether the term was used to refer to substance when it was explicitly linked to a certain policy, or rather to a particular style, such as manner of speech or even appearance. The third 
option was that populism was used in an undefined way, without much of a hint as to what was meant by the term. Also the number of times the words 'populism' or 'populist' appeared was recorded and we took into consideration whether these terms appeared in the headline of the article or not. In order to get a sense of the actors who were labelled populists, we noted who or what was referred to when the term was used, as well as which country was concerned. It was also considered whether it was the journalist who used the term, or rather a politician who was quoted as doing so, or someone else ${ }^{2}$.

Finally, we assessed whether populism was used in a positive, negative or neutral way. We took a rather conservative approach in this regard. In a substantial number of articles the term seemed to be used somewhat pejoratively, but in a rather implicit way which required some reading between the lines. As the use of the term in these instances was not unambiguously negative, we coded the reference as negative only when there was an explicit negative value judgement about the alleged populist actor or issue involved. To ensure inter-coder reliability we recorded the negative words associated with each of these instances.

The following sections provide the findings of the analysis. Firstly, some general observations are highlighted. Next, we move to the articles dealing exclusively with politics and consider which actors are labelled 'populist'. Subsequently, the policies associated with populism are discussed. Following this, we focus on whether populism tends to be used in a pejorative way and, finally, we will look at whether there is any systematic variation in the way different newspapers employ the term.

\section{Some general observations}

We focus on the more 'highbrow' broadsheet papers rather than the more widely read 'tabloid' papers, primarily because the terms 'populism' and 'populist' are used so sparingly in these more 'downmarket' outlets. For instance, the search generated only 32 articles for the period July-September 2008 when five tabloid papers were selected. The best-selling Sun and The Mirror contained one article each and The Star (whose political coverage has always been minimal) did not include a single article that contained 
the words 'populism' or 'populist'. Its stablemate, the slightly more upmarket Express contained eight. But by far the most articles were found in the 'least tabloid' of the tabloids, The Mail (21) where, when it was not mentioned (as in the Express) in the course of covering the US presidential race, it was used to label the left and in particular the Scottish National Party and its policies (such as free hospital parking and the call for abolition of university tuition fees) ${ }^{3}$, thereby hinting at a partisanship which was also evident in the other tabloids. For instance, in the one article in which the terms 'populism' and 'populist' appeared in the Labour-supporting tabloid, the Mirror, the paper used it to condemn Conservative leader David Cameron's apparently simplistic call to lock up more criminals.

The total number of articles generated from the four broadsheet newspapers we concentrated on was 676 . With regard to the first period, the search yielded 358 articles which contained the words populism or populist; in the second period 318 articles were found. The overwhelming majority of the articles mention either one of the terms only once. Furthermore, in only $2.5 \%$ of the articles did the terms appear in the headline of the article, signifying that populism is almost never a central concept in news coverage. Breaking the use down further, it becomes apparent that 'populist' is used much more than 'populism', indicating that the term is most often used as an adjective, referring to a particular actor, issue or policy, and not as a concept or a phenomenon ${ }^{4}$.

As for the sections of the paper in which the selected articles appeared, most articles appeared in the news sections (43\%) and in the op-ed section (35\%). Only a handful of the articles are letters from readers, while the remaining fifth of the items are reviews, mostly dealing with non-political topics such as art and media. With regard to the person who actually uses the term, this is clearly most often the journalist or author of the (op-ed) piece ( $87 \%$ of the time), rather than another person (such as a politician) quoted describing someone or something as populist.

Further, an analysis of the topics dealt with in the articles shows us that in twothirds of the articles the content is related to politics. Most of the other articles can be subdivided in three categories: arts (17\%), media (10\%) and sports (3.5\%). If only 
articles reporting on Britain are taken into account, only about half of the articles mention populism in a political context. The other, non-political, articles predominantly deal with arts, media and sports in Britain. Remarkably, in the articles covering sports the actor (often a football coach) is perceived as populist when making a decision which is in line with the preferences of the crowd (e.g. selecting a popular player). The articles dealing with media or arts generally refer to TV programs or presenters, artists (actors, musicians, writers etc.) or their works of art (for instance, musicals, ballet performances). In the articles in this category 'populism' is either used neutrally, for instance to suggest that a particular work of art (broadly described) is popular or accessible to a large audience, or more pejoratively, to indicate that said work is rather unsophisticated and enjoyed by hoi-polloi who have not developed a keen eye for such matters. ${ }^{5}$

\section{The populist political actors}

The remainder of the article, however, will focus not on the arts or other topics but on the majority of the articles that deal with politics. The majority of these (56\%) use the term 'populism' to refer to a particular policy, whilst a third of them use it in an undefined way: actors are simply described to be populist without any further justification or clarification. Finally, in one in ten cases 'populism' indicates a particular style related to a politician's appearance or manner of speech.

Table 1 depicts a list of political actors which have been labelled 'populist' at least three times for each of the two periods of study. As it turns out, next to the United Kingdom a wide range of countries is covered, indicating that the media's use of the term does not seem to be confined to a particular geographical region. Nor, since a wide range of actors from completely different political backgrounds can be found the table, does the populist label seem to be reserved for parties or politicians subscribing to a particular political ideology. It is for instance not directly evident what Iranian president Ahmadinejad, the prospective president of the United States Barack Obama and the Scottish National Party (SNP) have in common. Moreover, it is striking that politicians 
from rival political parties are considered to be populist: in the UK both the Conservatives and Labour politicians are well represented, as are both Democrats and Republicans in articles covering the US.

\section{$* * *$ TABLE 1 HERE $* * *$}

A closer look at the articles including individuals that are frequently labelled as populists provides us with some insights into why these actors are associated with the term. In first period of study, the top three spots are occupied by a distinctly mixed trio. Number one is the current president of South Africa, who was at the time running for the ANC leadership and often in the news due to the corruption scandals in which he was thought to be involved. If what is meant by the term is specified, the populism in Zuma's case is occasionally attributed to his proposed policies (e.g increasing social spending, making education free of charge or introducing the death penalty) or his style. His populism has for instance been related to the fact that he 'enjoys posing in loincloth with Zulu shield' (Sunday Times, 23-12-2007). This hardly applies - some would say thank goodness - to UK Prime Minister Gordon Brown, number two on the list. If anything, in fact, the rather, stiff, informal style of Gordon Brown is often blamed for his lack of appeal to the average British voter. Instead, he is perceived to be populist because of his policy proposals, in particular those related to lowering income tax and improving health care, and because of what some saw as his unwise (and undeliverable) commitment to provide 'British jobs for British workers' (e.g. Independent, 13-11-2007). Number three is Hugo Chavez, perhaps the most usual suspect among these politicians, in view of his 'man on the street' appearance and 'power to the people' rhetoric. His populism is also often associated with anti-Americanism, redistributive social policies and nationalisation of industries.

The top three of the second period includes the two rival US presidential candidates Barack Obama and John McCain. Interestingly, all but one of the references to these politicians are found in articles from September only, when the elections were 
beginning to draw near. It is noticeable that the two rivals are both considered to be populist, and it is also striking how often both men are labelled populist in the very same article. Their populism is very often related to their critique of Wall Street or corporate greed, a hot topic at the time due to the prevailing economic crisis. The UK Labour government occupies third place in the second period, due to the alleged populism of policies that include lowering stamp duty on house purchases in order to kick-start the residential property market, baling out homeowners with public money and the consideration being given to a windfall tax on money-making energy companies.

Other notable political figures that appear frequently are Zulfikar Ali Bhutto, the father of the murdered Pakistani presidential candidate Benazir Bhutto, who herself is only directly associated with populism on one occasion. The US presidential candidates Huckabee and Edwards also pay a return visit. In fact, a brief look at the other articles of 2007 revealed that most of the US presidential candidates are linked to populism at one time or another. Further, European radical right-wing parties, such as the Swiss SVP and its leader Christoph Blocher and the Austrian FPÖ and its late leader Jörg Haider are repeatedly - perhaps even routinely - associated with populism.

If the articles covering British politics are considered more closely - and nearly half (45\%) of all the politics articles deal with politics in the UK - it is evident that the Labour Party is the party most associated with populism. Including government ministers, MPs or the party as a whole, the party is linked with populism 84 times (44 times in the first period, 40 times in the second). The Conservative Party is linked with populism 39 times (26 and 13 times respectively). This difference is not entirely surprising: not only do many of the references touch on policies that the Labour government was proposing but that government was, moreover, coming in for increasing criticism from the media and from ever more disillusioned voters. The Scottish National Party, in turn, is labelled populist on 22 occasions. Notably, the Liberal Democrats, the 'third party' in the UK's traditionally two-party system - and therefore one which often struggles for media coverage between elections - are associated with populism only once in the first period, but eight times in the second. 
Although, overall, the list of individuals and parties seems to be rather random, there are some similarities between the lists of the first and second period under consideration. That is, some actors, such as Gordon Brown, Jacob Zuma and US presidential candidates are associated with populism in both periods, indicating that something clearly seems to render these particular actors populist in the eyes of the journalists. In many cases their populism tends to be linked to (social) policies or critiques of corporate greed which are implicitly assumed to appeal to a substantial (if not necessarily well-informed) part of the electorate. This seems to indicate that the adjective 'populist' is often used as a synonym for 'popular'.

That said, the most important reason why particular actors are associated with populism simply seems to be the amount of media attention that is spent on a particular topic in a given period of time. Thus, it seems that any political actor who is in the news frequently for a substantial amount of time probably runs the risk of being labelled 'populist' sooner or later. The high ranking of a whole range of US presidential candidates

in both periods is a case in point. This suspicion seems to be confirmed by a brief investigation of the articles in May 2007, which reveals that Nicolas Sarkozy is often associated with populism, mainly as a function perhaps of the presidential electoral campaign in France that was taking place at the time.

\section{The populist issues}

All in all, although there may well be particular reasons for labelling actors 'populist', these reasons seem very diverse and diffuse. Will we find more coherence when we assess in greater detail the policies that are associated with populism in the print media? The answer to this, perhaps unsurprisingly, must be 'no'. Table 2 lists some policy positions that have been labelled 'populist' and indicates these are basically 'all over the shop', ranging from anti-Iraq war to anti-supermarket. Moreover, the table also shows that the policy positions travel easily throughout the left-right political spectrum; the lefthand column representing the political left and the right-hand column the political right. Thus, when it comes to economic and social programmes, the populist label is applied 
both to public spending issues, like free education and cheap healthcare, and to issues like tax cuts and other pro-market stances. Apparently, arguing for increased taxes on the rich and favouring a flat tax are both apparently populist standpoints. The same goes for calling for the public funding of parties and being dead set against it.

$* * *$ TABLE 2 HERE $* * *$

Interestingly, if we look at the issues not directly related to socio-economic issues, but those that can instead be placed on a 'cultural' or 'postmodernist' left-right dimension, we can observe more of a logical pattern. Defined in these terms we see that right-wing issues, such as being against immigration, being in favour of building prisons and extending detention periods for terrorist suspects, are overrepresented in the table. Being anti-Iraq war, if this is perceived as a left-wing stance, can be seen as an exception to this, but overall the relationship seems quite strong. There seems, then, to be no logic in the employment of 'populism' as regards socio-economic issues like social justice, taxation and government spending. With regard to non-economical issues such as immigration and handling crime, however, populism seems to be mainly associated with policies traditionally identified with the political right rather than the left.

\section{The pejorative use of populism}

So far, then, we might conclude that, as in the academic usage, populism and populist are employed in a rather random way. The actors and issues to which the concept is related seem to have little in common. A next step is to take into account the print media's evaluative or normative use of the terms. Can we observe a similar tendency to use the terms pejoratively? At first glance, Table 3 indicates that in two-thirds of the articles populism is used in a neutral way. Remember, however, that articles were coded as 'negative' only when populism was explicitly - rather than only implicitly - used in a pejorative sense - a decision which, although it made coding more straightforward and made for intercoder reliability by leaving less leeway for interpretation, may well have 
understated how often some sort of negative connotation was involved ${ }^{6}$. Certainly, in the remainder of the articles 'populism' clearly tends to be used pejoratively $(29.0 \%$ of the articles), whereas the term is only used positively in a small minority (4.3\%) of all the articles.

$* * *$ TABLE 3 HERE $* * *$

If only the articles covering political issues are considered, these figures do not change much: only slightly more articles use populism in a negative sense $(33.4 \%)$, for instance. Remarkably, the figures do change quite drastically if we break down the articles per region. Accordingly, when populism is used in articles covering British politics, the term is used pejoratively getting on for half $(43.6 \%)$ of the time, while in articles covering politics outside the UK the term is only used negatively about a quarter of the time. As a substantial number of articles dealt with politics in the USA, these articles are taken as a subcategory, but they do not substantially differ from articles covering politics in other non-British countries in terms of the normative use of populism. It seems that 'populism' tends to be used descriptively more often when politics abroad is concerned, whereas with regard to domestic politics the term is more often employed in a pejorative sense. Possibly, this simply stems from the fact that journalists have a clearer idea (and opinion) about domestic than they do about international politics.

Also, the fact that a large number of op-ed pieces are written on British politics is likely to play a role. In other words, if we distinguish between news coverage and op-ed articles we observe see that in 'straight' news coverage populism tends to be used in a neutral sense much more often compared to its use in op-ed articles. In news coverage the term is used neutrally $61.9 \%$ of the time, and pejoratively $32.4 \%$ of the time. The figures with regard to op-ed articles, which are by their very nature marked by a more normative, opinionated style, are $49.5 \%$ and $43.0 \%$ respectively. Also, the percentage of positive references in op-ed articles is higher $(7.5 \%)$, although the actual number of articles in this category - seven - is a bit too low to provide conclusive evidence. 
Overall, populism, even under our rather strict coding scheme, can be said to be used in a pejorative way reasonably frequently. Even if a majority of the articles use populism, strictly speaking, in a neutral way, the instances in which populism has a normative connotation are almost always instances in which populism is used pejoratively. The next section is also largely related to the connotation of populism and deals with the way populism is employed in the different newspapers.

\section{Populism per newspaper}

Finally, we can look at the use of populism distinguishing between the different newspapers in our sample. It turns out that there are some notable differences if we compare the four newspapers with regard to the normative usage of populism, the actors referred to and the issues and policies related to populism. These differences become even more notable when the newspapers are placed on an ideological left-right scale (see table 4). First of all, the two newspapers located toward the political centre, the (Laboursupporting, at least at elections) Guardian and the Times (which often changes which party it endorses at election time), use populism more often than the two less centrist broadsheets, the Independent (which tends to favour the Liberal Democrats who are now located to the left of Labour), and the Telegraph (the so-called 'house-journal' of the Conservative Party).

\section{$* * *$ TABLE 4 HERE $* * *$}

Irrespective of the number of times the terms 'populism' and 'populist' are mentioned (the papers nearer the centre seem to use them for some reason more than those on the flanks), our data reveals that the extent to which the terms are used in a pejorative sense varies according to newspaper. If the political signature of the different papers is taken into consideration, however, it is not easy to identify a very straightforward logic. That is, the papers that use populism most pejoratively, the Independent and the Times, can be labelled as left-wing and centre-right newspapers 
respectively. On the other hand, the newspapers that use populism pejoratively slightly less often, the Guardian and the Telegraph, are respectively centre-left and right-wing. Clearly, the left-wing Independent tends to use populism in the most negative sense: in $38.7 \%$ of all articles and $44.0 \%$ of the articles on politics the term is employed pejoratively. Populism is rarely used as a 'hurrah-word' on either side of the political spectrum, but it would appear to be more of a 'boo-word' (see Cranston, 1953) for leftwingers than it is for right-wingers. This comes as no great surprise as we have seen that (at least with regard to non-economical issues) populism tends to be associated with traditionally right-wing stances.

If the alleged populist actors mentioned in the coverage are taken into account for each newspaper the names which come up are very similar to those which appear in Table 1. Yet, a closer look at the number of times the different (British) actors are referred to per newspaper points us to an interesting difference. Namely, where the Telegraph, Times and Guardian most frequently use 'populism' to refer to the Labour Party and Labour politicians, the Independent employs the label more often for the Conservatives - at least in the first period. In the second, the 'Indy' seems more preoccupied, in fact, with criticising Gordon Brown's government than its opponent, while the Guardian seems equally happy to tar Labour and the Conservatives with the same brush (albeit for different reasons). All this suggests, firstly, that newspapers use the label populist to target actors on the other side of the political spectrum but, secondly, that, especially when they sit on the left of that spectrum, newspapers will use the same label to express disapproval of politicians and parties who are ostensibly on their side of that spectrum when those politicians and parties supposedly 'pander to public opinion'.

We see a similar logic when we consider which issues and policies are deemed to be populist by the different newspapers. The Telegraph tends to refer more to left-wing policies, such as health care spending and income redistribution, not least, for instance, when considering hints that the government may be tempted to levy windfall taxes on overly-profitable utility companies. This possibility also worried the Times, although generally the latter seems equally concerned about policies that are traditionally 
associated with the left and those traditionally associated with the right. The Guardian and the Independent, however, refer more to right-wing issues such as tax-cutting and xenophobia. Thus, taking into account the political affiliation of the individual newspapers, it seems that we are able to distinguish a left-right divide in the way populism is used. Firstly, the most left-wing paper uses the term 'populism' pejoratively much more frequently than the other papers. Secondly, irrespective of the explicit connotation of the term, the newspapers tend to use the words 'populism' and 'populist' for actors and policies on the opposite side of the political spectrum. Populism is a term which tends to be reserved for the political 'enemy', which implicitly seems to turn it into a term of abuse, even if it is not unambiguously used in a negative way.

\section{Conclusion and discussion}

We decided not to include the Financial Times in our analysis on the grounds that it contains fewer news pages than the other broadsheets, rendering comparison difficult. But a glance at a recent edition suggests that it may not be so very different, either from them or from its fellow champion of good governance and liberalism, the Economist. The UK government's so-called Pre Budget Report on 8 December 2009 provided a last chance for the Chancellor of the Exchequer to set out a plan that would, at one and the same time, rescue the British state from its massive budget deficit and rescue Labour from a near certain electoral defeat. Predictably enough, it was greeted with little enthusiasm. According to the FTs columnist, Philip Stephens, writing the next day:

anyone looking for a grand strategy soon found themselves lost in the plethora of micromeasures calculated to draw political dividing lines with the Conservatives. Populist pledges to protect 'frontline services' such as hospitals, schools and police numbers belied the gravity of the challenge.

This, claimed the headline accompanying his column, was 'Populism without purpose'. What can we conclude from our investigation? First of all, the terms 'populism' 
and 'populist' are practically never central to the content of the articles in which they appear, and they are generally not defined very well. Secondly, it is clear that the terms populist and populism are used for a wide range of individuals and political parties that seem to have little in common. The terms are used for political actors from all sorts of different ideological backgrounds: from Gordon Brown to Hugo Chavez and from Barack Obama to the Scottish National Party. Thirdly, the concept travels - we might even say 'stretches' - extremely well: actors from a variety of continents, and/or their policies, are deemed populist. Fourthly, if we look at particular issues and policies connected to populism we see that both left-wing as well as right-wing causes, and sometimes even causes which would seem to be almost the exact opposite of each other, are labelled 'populist'. Although when we focus on non-economical issues such as crime and immigration, populism is more often linked with the political right, any logic with regard to socio-economic issues seems to be lacking. Fifthly, populism, especially in articles covering British politics and op-ed articles, is often used pejoratively. Finally, if we distinguish between the four sources we selected we can see that there is a tendency to label something from the opposing side of the political spectrum as 'populist'. This indicates that populism is used as a negative label to pin on one's political enemies and their stances and policies. However, we also noted that it is sometimes used - probably more often on the left than on the right, to criticise even those on one's own side who 'pander to public opinion', especially if that (majority) opinion runs counter to that of the newspaper in question.

All in all, there is enough reason to concur with the author of the letter to the Economist with which we began this article: populism is indeed a term which is 'thrown around with abandon'. Especially when we look at the list of alleged actors labelled populist by the so-called 'quality' newspapers in the UK, logic seems to disappear out of the window: it almost seems as if any political actor that receives sufficiently extensive news coverage will be labelled 'populist' sooner or later. But is populism simply a 'hollow term of abuse'? Our finding that a substantial share of the populist references was pejorative, and the finding that left-wing newspapers use the term more often to refer to 
right-wing policies and politicians, and vice versa, does seem to confirm this. On the other hand, it is noticeable that populism often seems to be used as a synonym for 'popular', albeit rather implicitly. A policy (e.g. cutting tax, free education) is often labelled 'populist' when it is likely to please the electorate, i.e. it is seen as a votewinning policy. Still, populism in this sense may have a negative connotation as well: politicians are supposedly driven merely by the urge to win votes and are therefore proposing these 'populist' policies.

If we consider the language in newspapers as ordinary, day-to-day language, what are the implications of our findings when we return to the academic use of the term? Unfortunately, the most obvious consistency between the vernacular and academic use seems to be that populism is a highly ambiguous concept in both senses. Also in academic contributions a variety of often quite unrelated actors are labelled as 'populist' and the term is frequently used in a pejorative way as well. That said, there are some fruitful academic contributions use the concept a bit more carefully (e.g. Ionescu and Gellner 1969; Canovan 1981; 1999; Betz 1994; Taggart 2000; Mudde 2004; 2007; Mény and Surel 2002; Laclau 2005; Rydgren 2005; Albertazzi and McDonnell 2008; Abts and Rummens 2007; Barr 2009).

But even if we assume that the concept is used in a more systematic way academically, the almost random use of the term in vernacular language still poses a problem. If we believe that the vernacular and academic use of concepts needs to be consistent in order for the concept to be meaningful, or at the very least allows academics to nurture some hope that their work will impact, albeit indirectly, on a lay audience $^{7}$, we may conclude that we had better ban the term populism from our scholarly vocabulary altogether.

This does not appear to be the most sensible solution, however. The term has been coined and is used extensively in debates inside and outside academia and, as we contend, populism can surely be a meaningful concept to describe a political phenomenon that has enjoyed something of a resurgence in recent years, most notably in the shape of new political parties. In using the term, however, the least academics can 
do is to be conscious of the ambiguity of the term in the vernacular and to be careful in employing the concept in a more systematic way themselves.

As regards scope for further research, it would obviously be interesting to investigate the use of populism in other countries' news media and to compare the results to the British case. Populism is a word with quite different connotations in different languages, it would therefore be interesting to see if the pejorative use of the term prevails also in other languages and if the word is 'thrown around with abandon' to the same extent as is the case in the British print media.

Word Count:@@@(incl. Notes, bibliography and tables),date: @@@

\section{Notes}

\footnotetext{
${ }^{1}$ Using a concept coined by Michael Freeden (1998), authors perceiving populism as a 'thin' or 'thin-centred' ideology basically argue that populism in itself does not provide an all encompassing framework of how society should function. As a result, parts of existing, more rooted ideologies can and should be added to the populist core.

${ }^{2}$ With regard to the section in which the articles appeared and the person using the term only the articles in the second period (July-September 2008) were coded.

${ }^{3}$ Interestingly, in our sample The Mail is the only UK paper to provide a definition of 'populism' in an article answering readers queries and explaining Wizard of $\mathrm{Oz}$ as 'coded political satire': 'Populism is a Left-wing political doctrine that proposes that the rights and powers of ordinary people are exploited by a privileged elite, and it supports their struggle to overcome this.' (Daily Mail, 02-09-2008).

4 The remainder of this article will nevertheless use the terms 'populist' and 'populism' interchangeably.

${ }^{5}$ A reviewer for instance qualifies Scott McKenzie's classic song San Francisco as a "drippy piece of populist fakery [which] sold the hippie idyll to the masses" (Observer, 13-07-2008, p.8).
} 


\footnotetext{
${ }^{6}$ See the discussion in the section 'Populism per newspaper'.

${ }^{7}$ Which is an aspiration that needs to be fulfilled if, in Britain at least, academics are to score well in government-run research evaluations that drive university funding (see Collini 2009).
}

\section{Bibliography}

Abts, K. and Rummens, S. (2007) Populism versus Democracy. Political Studies 55(6): 405-24.

Albertazzi and McDonnell (2008) Introduction: The Spectre and the Spectre. In: Albertazzi, D. and McDonnell, D. (eds.) Twenty-First Century Populism. The Spectre of Western European Democracy. Basingstoke: Palgrave MacMillan, pp. 111.

Barr, R. (2009) Populists, outsiders and anti-establishment politics. Party Politics, 15(1): $29-48$.

Betz, H.-G. (1994) Radical Right-Wing Populism in Western Europe. New York: St. Martin's Press.

Canovan, M. (1981) Populism. New York and London: Harcourt Brace Jovanovich.

Canovan, M. (1999) Trust the People! Populism and the Two Faces of Democracy. Political Studies, 47(1): 2-16.

Collini, Stefan (2009) Impact on humanities: Researchers must take a stand now or be judged and rewarded as salesmen, Times Literary Supplement, 13 November, http://entertainment.timesonline.co.uk/tol/arts and entertainment/the tls/article 6915986.ece, accessed 13 December 2010.

Cranston, Maurice (1953) Freedom: a New Analysis. London: Longman.

Freeden, M. (1998) Is Nationalism a Distinct Ideology?. Political Studies 46(4): 748-65.

Ionescu, G. and Gellner, E. (eds.) (1969) Populism, its Meanings and National Characteristics. London: Weidenfeld and Nicolson.

Laclau, E. (2005) On Populist Reason. London, New York: Verso. 
Mény, Y. and Surel, Y. (2002) The Constitutive Ambiguity of Populism. In: Mény, Y. and Surel, Y. (eds.) Democracies and the Populist Challenge. Basingstoke: Palgrave, pp. 1-21.

Mudde, C. (2004) The Populist Zeitgeist. Government and Opposition 39(4): 542-63.

Mudde, C. (2007) Populist Radical Right Parties in Europe. Cambridge: Cambridge University Press.

Rydgren, J. (ed.) (2005) Movements of Exclusion. Radical Right-Wing Populism in the Western World. New York: Nova Science Publishers.

Taggart, P. (2000) Populism. Buckingham and Philadelphia: Open University Press.

Taggart, P. (2002) Populism and the Pathology of Representative Politics. In: Mény, Y. and Surel, Y. (eds.) Democracies and the Populist Challenge. Basingstoke: Palgrave, pp. 62-80.

Taggart, P. and S. van Kessel (2009) The Problems of Populism, Paper presented at the annual Dutch-Flemish conference Het Politicologenetmaal, 28-29 May, Berg en Dal, The Netherlands.

Worsley, P. (1969) The Concept of Populism. In: Ionescu, G. and Gellner, E. (eds.) Populism, its Meanings and National Characteristics. London: Weidenfeld and Nicolson, pp. 212-250. 
Table 1: Political actors labelled 'populist' at least three times.

\begin{tabular}{|l|l|r||l|l|r|}
\hline October-December & \multicolumn{3}{l|}{ July-September 2008} \\
\hline Actor & Country & \# & Actor & Country & \# \\
\hline Jacob Zuma & South Africa & 23 & John McCain & United States & 26 \\
\hline Gordon Brown & United Kingdom & 20 & Barack Obama & United States & 14 \\
\hline Conservative Party & United Kingdom & 16 & Labour Government & United Kingdom & 11 \\
\hline Hugo Chavez & Venezuela & 12 & Labour Party & United Kingdom & 10 \\
\hline Christoph Blocher & Switzerland & 9 & Jacob Zuma & South Africa & 9 \\
\hline Scottish Nat. Party & United Kingdom & 8 & Conservative Party & United Kingdom & 8 \\
\hline Zulfikar Ali Bhutto & Pakistan & 8 & Sarah Palin & United States & 8 \\
\hline Mike Huckabee & United States & 7 & Liberal Democrats & United Kingdom & 6 \\
\hline John Edwards & United States & 8 & Gordon Brown & United Kingdom & 5 \\
\hline Thaksin Shinawatra & Thailand & 6 & Alex Salmond & United Kingdom & 5 \\
\hline Nestor Kirchner & Argentina & 6 & Scottish Nat. Party & United Kingdom & 5 \\
\hline Labour Party & United Kingdom & 6 & Jörg Haider & Austria & 4 \\
\hline Alistair Darling & United Kingdom & 5 & FPÖ & Austria & 4 \\
\hline David Cameron & United Kingdom & 4 & David Cameron & United Kingdom & 3 \\
\hline M. Ahmadinejad & Iran & 4 & AK Party & Turkey & 3 \\
\hline John Howard & Australia & 4 & Nicolas Sarkozy & France & 3 \\
\hline Labour Government & United Kingdom & 4 & SNP Government & United Kingdom & 3 \\
\hline Christina Kirchner & Argentina & 4 & Alan Johnson & United Kingdom & 3 \\
\hline Evo Morales & Bolivia & 3 & Thaksin Shinawatra & Thailand & 3 \\
\hline Rafael Correa & Ecuador & 3 & & & \\
\hline Self-Defence Party & Poland & 3 & & & \\
\hline Silvio Berlusconi & Italy & 3 & & & \\
\hline
\end{tabular}


Table 2: Issues associated with populism' (October- December 2007, July-September 2008).

\begin{tabular}{|l|l|}
\hline 'Left-wing' issues & 'Right-wing' issues \\
\hline Advocate Public spending & For individual materialism \\
For Capital Gains Tax & For tax cuts \\
For taxing the very rich & For flat tax \\
Anti-Wall Street & Against inheritance tax \\
Anti-Iraq War & Controlling or stopping immigration \\
For cheap health care & Building prisons \\
For social justice & Cutting crime \\
Free medical prescriptions & Anti-public sector targets \\
Free education & Euroscepticism \\
Anti-supermarket & Strong state and free individuals \\
For nationalising industries & 'Islamophobia' \\
Economic protectionism & Holding terrorist suspects longer \\
Pro-poor & Pro-market \\
For public funding of parties & Against public funding of parties \\
For Windfall tax & Cutting fuel tax \\
Opposition to nuclear power & Tough on crime \\
Supporting domestic car industry & Restricting immigration \\
Saving hospitals & Reducing road tolls \\
\hline
\end{tabular}


Table 3: Connotation of 'populism' per category

\begin{tabular}{|l|r|r|r|r|}
\hline & Neutral & Negative & Positive & Total \\
\hline All & $451(66.7 \%)$ & $196(29.0 \%)$ & $29(4.3 \%)$ & 676 \\
\hline Politics & $286(63.3 \%)$ & $151(33.4 \%)$ & $15(3.3 \%)$ & 452 \\
\hline UK & $104(51.5 \%)$ & $88(43.6 \%)$ & $10(5.0 \%)$ & 202 \\
\hline USA & $52(71.2 \%)$ & $18(24.7 \%)$ & $3(4.1 \%)$ & 73 \\
\hline Other Countries & $130(73.4 \%)$ & $151(25.4 \%)$ & $15(1.1 \%)$ & 177 \\
\hline Political News & $64(61.9 \%)$ & $34(32.4 \%)$ & $6(5.7 \%)$ & 105 \\
\hline Political Op-Ed & $46(49.5 \%)$ & $40(43.0 \%)$ & $7(7.5 \%)$ & 93 \\
\hline
\end{tabular}


Table 4: Use of populism per newspaper

\begin{tabular}{|l|l|l|l|l|}
\hline & $\begin{array}{l}\text { Independent } \\
\text { Left-Wing }\end{array}$ & $\begin{array}{l}\text { Guardian } \\
\text { Centre-Left }\end{array}$ & $\begin{array}{l}\text { Times } \\
\text { Centre-Right }\end{array}$ & $\begin{array}{l}\text { Telegraph } \\
\text { Right-Wing }\end{array}$ \\
\hline All & 111 & 236 & 237 & 92 \\
\hline Pejorative & $43(38.7 \%)$ & $57(24.2 \%)$ & $72(30.4 \%)$ & $24(26.1 \%)$ \\
\hline Politics & 91 & 148 & 150 & 63 \\
\hline Pejorative & $40(44.0 \%)$ & $40(27.0 \%)$ & $54(36.0 \%)$ & $17(27.0 \%)$ \\
\hline $\begin{array}{l}\text { Who (in } \\
\text { the UK)? }\end{array}$ & $\begin{array}{l}\text { Conservatives } \\
\text { Labour }\end{array}$ & $\begin{array}{l}\text { Labour } \\
\text { Conservatives }\end{array}$ & $\begin{array}{l}\text { SNP } \\
\text { Labour } \\
\text { Conservatives }\end{array}$ & $\begin{array}{l}\text { Labour } \\
\text { SNP } \\
\text { Conservatives }\end{array}$ \\
\hline What? & $\begin{array}{l}\text { Anti-immigration. } \\
\text { Anti-minority. } \\
\text { Tax-cutting. } \\
\text { Euroscepticism. }\end{array}$ & $\begin{array}{l}\text { Tax-cutting. } \\
\text { Tough on } \\
\text { crime. } \\
\text { Anti- } \\
\text { immigration. } \\
\text { Anti-minority. }\end{array}$ & $\begin{array}{l}\text { Public Spending. } \\
\text { Anti-immigration. } \\
\text { Nationalism. } \\
\text { Protectionism. } \\
\text { Euroscepticism. } \\
\text { Tax-cutting or } \\
\text { raising. }\end{array}$ & $\begin{array}{l}\text { Realth spending. } \\
\text { State int'vention. } \\
\text { Tax-cutting or } \\
\text { raising. } \\
\text { Following public } \\
\text { opinion. } \\
\text { Regulating. }\end{array}$ \\
\hline
\end{tabular}

